\title{
Catalytic decomposition of p-cymene by activated clay.
}

\author{
By Masafumi Maki
}

(formerly of Meguro Institute of Chemical Research of Mitsui Chem. Ind. Co., Ltd.)

SYNOPSIS :- Reaction mechnism of catalytic decomposition of p-Cymene by activated clay was studied and decomposition degree with the change of reaction temperature and space velocity was measured. Beside the main dealkylation reaction, dehydrogenation and demethanation reaction were occured as side reaction. Changes of amount of toluol and propylene obtained by dealkylation of p-cymene were nearly parallel with temperature change and space velocity change, and the dealkylation ability of catalyst could be compare by the quantity of propylene approximately.

U. D. C. $66.097: 547.536 .21-023$

\section{シリカーアルえナ型触媒による $\mathrm{p}-\mathrm{Cymene} の$ 接触分解反応}

一一昭和 28 年 4 月 17 日受理一

$$
\text { 元三井化学目黑研究所 牧 正 文 }
$$

要旨 調製法を異にするシリカーアルミナ触媒を用い p-cymene 索高溫に把いて接触分触してその 分解機構を検討し，かつ各触媒の脫アルキル分解能を比較した。また周期律表第 $2,3,4$ 属元素の酸化 物を組合せた二成分触媒についても同じ实験を試みた。 $\mathrm{SiO}_{2}-\mathrm{MgO}, \mathrm{Al}_{2} \mathrm{O}_{3}-\mathrm{B}_{2} \mathrm{O}_{3}, \mathrm{Al}_{2} \mathrm{O}_{3}-\mathrm{ZrO}_{2}$ が㧤 アルキル分触能の高いととを認めた。

また概略的ではあるが，乙れらの触媒中，シリカと上記周期律表中の酸化物を組合せた触媒はその 酸化物の金属元素の原子坐径の篔大とともに㧤アルキル分解によつて生成するプロビレン生成量が減 少することが贸められる。

前被に扣いて活性白土による p-cymene の分解機構について述べたが，本報に抽いては調製法を 異にするシリカーアルミナ触媒扣よびシリカあるいはアルミナに周期律表第 $2,3,4$ 属元素の酸化物 を組合せたシリカーアルミナ型二成分触媒による p-cymene の接触分解を和こない，分解機構を检 討しあわせて分解能の比鞼を和こなつた。

各触媒のX線备折結果をあわせて殸告する。

\section{（I）シリカーアルミナ触媒}

酸による精製度の高い活性白土ぶ p-cymene の脫 アルキル分解能か高いことは, 構造の似た合成シリ カーアルミナ触媒の分解能の高いであろらことを示唆 するものでをる。合成法を変えてつくつた種及のシリ カーアルミナ触媒を用いて p-cymene を高溫で分解 した結果第 1 表に示す。（括孤內の数字は原料 $\mathrm{p}$ cymene $100 \mathrm{~g}$ 使用のさいの各数量, プロビンはこの 場合 $\mathrm{g}$ で示す) 奏験法は前報の活性白土の場合と全く 同粎でをる。
脱アルキル分解能の比較は生成トルオールを子つて するのぶ正しいが前報でのべたと扣り大凡はプロピレ ン発生量で比較できるので，本報ではプロピレン量で 比較した。

\section{結果に対する考察}

1）脫アルキル分解能の高い $\mathrm{SiO}_{2}-\mathrm{Al}_{2} \mathrm{O}_{3}-2$ の場合 などは活性白土の場合と全く同稴な分解機構を示して おり, 主反応は脫アルキル反応で脫水素, 脫メタン反 応などは嚾少である。

2）プロピレン発生量のもつと多い触媒は珪酸y 


\section{第 1 表 シリカ一アルミナ型触媒による p-cymene の接触分解反応}

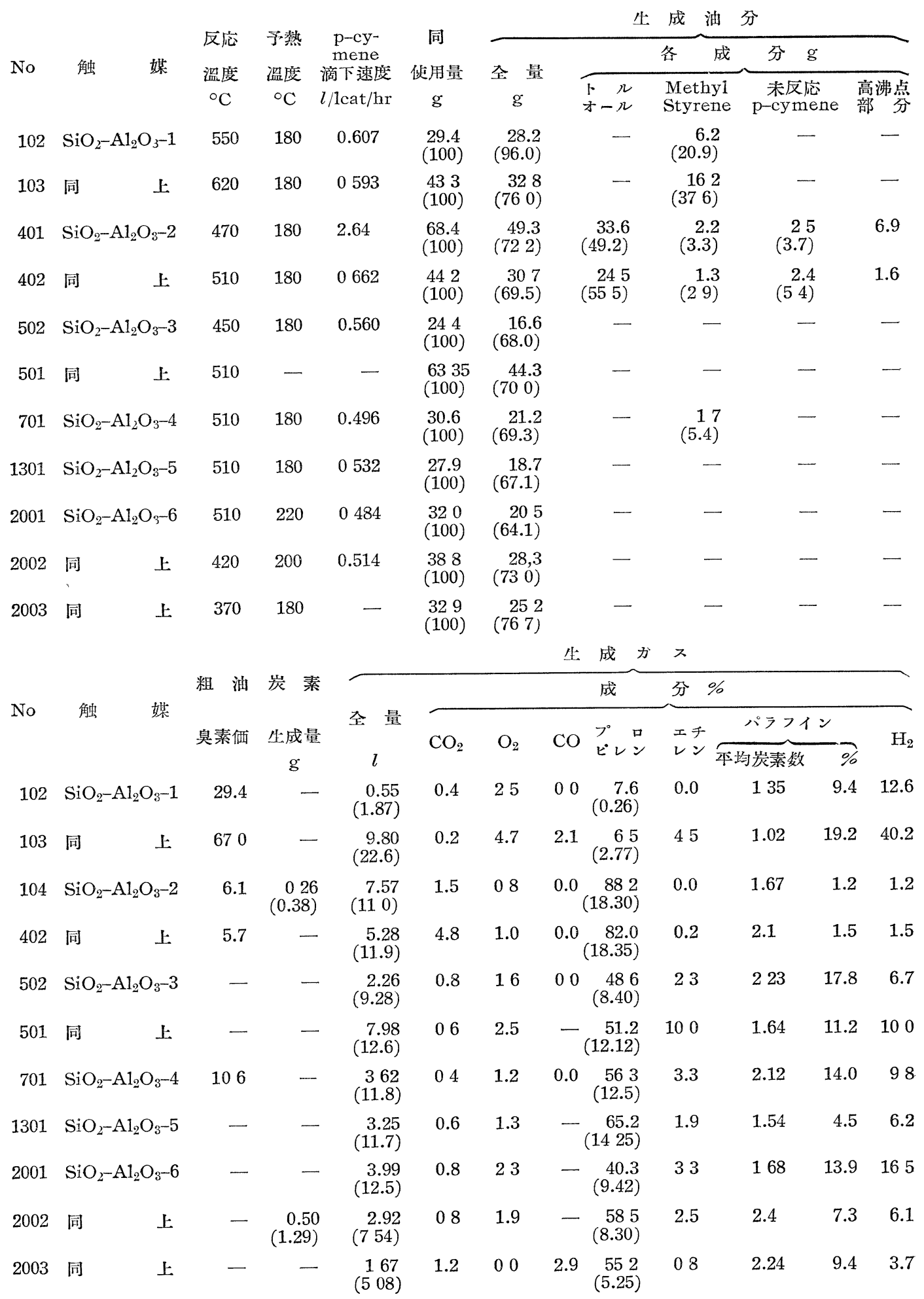


ーダとアルミ明ばんとの共沈法で调製した $\mathrm{SiO}_{2}-\mathrm{Al}_{2}$ : $\mathrm{O}_{3}-2$ で, 水素, パラフイン発生量も少く脫アルキル 以外の副反応の少いことを示している。2番目として はシリカゾルを用いた $\mathrm{SiO}_{2}-\mathrm{Al}_{2} \mathrm{O}_{3}-5$ て前述のものよ り多少水素, パラフイン量が堌加する。つぎにはシリカ ゲルを用いた $\mathrm{SiO}_{2}-\mathrm{Al}_{2} \mathrm{O}_{5}-3, \mathrm{SiO}_{2}-\mathrm{Al}_{2} \mathrm{O}_{3}-4$ がほとん と似炕結果を示している。後者は触媒调製途中水酸化 アルミニウムをつくるのに加水分解を用いて㧍り，前 者はアンモニアで沈港させている。ただし $\mathrm{SiO}_{2}-\mathrm{Al}_{2}$ $\mathrm{O}_{3}-3$ はェチレン発生量がかなり多い。シリカゾルと アルミナン゙ルとを混合してつくつた $\mathrm{SiO}_{2}-\mathrm{Al}_{2} \mathrm{O}_{3}-6$ は さらにプロピレン発生量が少く, 水素, パラフイン発 生量がかなり檑加している。以上各触媒を通観すると プロビレン発生量が順次隇少しているにもかかわらず 全発生ガス量に大美がないのは注目すべきことであ る。珪酸ソーダと硫酸アルミニウムから共沈法でつく られた $\mathrm{SiO}_{2}-\mathrm{Al}_{2} \mathrm{O}_{3}-1$ がガス発生量, プロピレン発生 量ともにきわめて少いのは意外で，本触媒調製のさい
焙㙯後非常に收縮してきわめてかたい触媒になつた ふ，これか吸着面積を減少させた一原因であつたかも しれない。

\section{触媒調製法}

$\mathrm{SiO}_{2}-\mathrm{Al}_{2} \mathrm{O}_{3}-1$ 玨酸ソーダ $250 \mathrm{cc}\left(\mathrm{SiO}_{2} 1.65 \mathrm{~mol}\right.$, $\mathrm{Na}_{2} \mathrm{O} 0.513 \mathrm{~mol}$ ) 含有) を水 $150 \mathrm{cc}$ て希鿬し, これ を $\mathrm{Al}_{2}\left(\mathrm{SO}_{4}\right)_{3} 18 \mathrm{H}_{2} \mathrm{O} 80.7 \mathrm{~g}$ を水 $350 \mathrm{cc}$ に溶解した溶

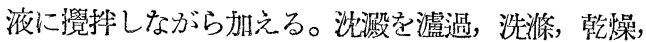
粉未化，錠剂とする。

$\mathrm{SiO}_{2}-\mathrm{Al}_{2} \mathrm{O}_{3}-2$ 珪酸ソーダ $400 \mathrm{cc}\left(\mathrm{SiO}_{2} \quad 0.64 \mathrm{~mol}\right.$, $\mathrm{Na}_{2} \mathrm{O} 0.20 \mathrm{~mol}$ 含有) を $\mathrm{KAl}\left(\mathrm{SO}_{4}\right)_{2} \cdot 12 \mathrm{H}_{2} \mathrm{O} 80 \mathrm{~g}$ を水 $150 \mathrm{cc}$ に溶解した溶液に $45^{\circ} \mathrm{C}$ で加え沈搌を瀘過 水洗，乾燥，錠凨とする。

$\mathrm{SiO}_{2}-\mathrm{Al}_{2} \mathrm{O}_{3}-3$ シリカゲルを硝酸アルミニウム溶液 に瀆けて抢き硝酸アルミニウムのしみこんだグルをと りだしてアンモニア水の中にいれ，ゲルの內部に水酸 化アルミニウムの沈澱をつくり，乾燥して用いる。

$\mathrm{SiO}_{2}-\mathrm{Al}_{2} \mathrm{O}$-4 $80^{\circ} \mathrm{C}$ で乾燥させたりシリカゲル 200

\section{第 2 表 シリカーアルミナ型触媒による p-cymene の接触分解反応}

\begin{tabular}{|c|c|c|c|c|c|c|c|c|c|c|}
\hline \multirow{3}{*}{ No. } & \multirow{3}{*}{ 触 } & \multirow{3}{*}{$\begin{array}{l}\text { 反応 } \\
\text { 溫度 } \\
{ }^{\circ} \mathrm{C}\end{array}$} & \multirow{3}{*}{$\begin{array}{l}\text { 予熱 } \\
\text { 濫䧹 } \\
{ }^{\circ} \mathrm{C}\end{array}$} & \multirow{3}{*}{$\begin{array}{c}\text { p-cy- } \\
\text { mene } \\
\text { 滴下速度 } \\
l / \text { lcat } / \mathrm{hr}\end{array}$} & \multirow{3}{*}{$\begin{array}{c}\text { 同 } \\
\text { 使用量 } \\
\mathrm{g}\end{array}$} & \multicolumn{5}{|c|}{ 生 成 油 分 } \\
\hline & & & & & & \multirow{2}{*}{ 全 $\mathrm{g}$} & \multicolumn{2}{|c|}{ 各 } & \multicolumn{2}{|l|}{ 分 $\%$} \\
\hline & & & & & & & 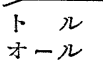 & $\begin{array}{l}\text { Methyl } \\
\text { Styrene }\end{array}$ & $\begin{array}{c}\text { 未反応 } \\
\text { p-cymene }\end{array}$ & $\begin{array}{l}\text { 高沸点 } \\
\text { 部 分 }\end{array}$ \\
\hline 801 & $\mathrm{SiO}_{2}-\mathrm{MgO}-1$ & 510 & 180 & 0.608 & $\begin{array}{r}33.4 \\
(100)\end{array}$ & $\begin{array}{r}23.15 \\
(69.3)\end{array}$ & - & - & - & - \\
\hline 901 & $\mathrm{Al}_{2} \mathrm{O}_{3}-\mathrm{ZrO}_{2}-1$ & 510 & 180 & 0.614 & $\begin{array}{c}26.3 \\
(100)\end{array}$ & $\begin{array}{c}18.1 \\
(68.8)\end{array}$ & - & - & - & - \\
\hline 902 & 上 & 510 & 180 & 0.976 & $\begin{array}{r}21.1 \\
(100)\end{array}$ & $\begin{array}{c}18.0 \\
(85.3)\end{array}$ & - & - & - & - \\
\hline 5001 & $\mathrm{Al}_{2} \mathrm{O}_{3}-\mathrm{ZrO}_{2}-2$ & 510 & 180 & 1.08 & $\begin{array}{c}21.0 \\
(100)\end{array}$ & $\begin{array}{c}18.7 \\
(89.2)\end{array}$ & - & - & - & - \\
\hline 3001 & $\mathrm{Al}_{2} \mathrm{O}_{3}-\mathrm{B}_{2} \mathrm{O}_{3}-1$ & 510 & 180 & 0.628 & $\begin{array}{r}28.9 \\
(100)\end{array}$ & $\begin{array}{c}19.1 \\
(66.2)\end{array}$ & - & - & - & - \\
\hline 1001 & $\mathrm{TiO}_{2}-\mathrm{B}_{2} \mathrm{O}_{3}$ & 510 & 180 & - & $\begin{array}{l}7.95 \\
(100)\end{array}$ & $6.0 \mathrm{cc}$ & - & - & - & - \\
\hline 1601 & $\mathrm{SiO}_{2}-\mathrm{CaO}-1$ & 510 & 180 & - & $\begin{array}{r}11.7 \\
(100)\end{array}$ & $12.0 \mathrm{cc}$ & - & - & - & - \\
\hline 1801 & $\mathrm{SiO}_{2}-\mathrm{CaO}-3$ & 510 & 180 & 0.457 & $\begin{array}{c}22.9 \\
(100)\end{array}$ & $23.0 \mathrm{cc}$ & - & - & - & - \\
\hline 1901 & $\mathrm{SiO}_{2}-\mathrm{CaO}-4$ & 510 & 180 & 0.578 & $\begin{array}{r}31.9 \\
(100)\end{array}$ & $35.0 \mathrm{cc}$ & - & - & - & $\ldots$ \\
\hline 1501 & $\mathrm{SiO}_{2}-\mathrm{SrO}-1$ & 510 & 180 & 0.637 & $\begin{array}{c}6.05 \\
(100)\end{array}$ & $4.8 \mathrm{cc}$ & - & - & - & - \\
\hline 1401 & $\mathrm{SiO}_{2}-\mathrm{ZnO}-1$ & 510 & 180 & 0.660 & $\begin{array}{c}29.8 \\
(100)\end{array}$ & $\begin{array}{c}25.2 \\
(84.7)\end{array}$ & - & - & - & - \\
\hline 1402 & $\mathrm{SiO}_{2}-\mathrm{ZnO}-2$ & 510 & 180 & 0.590 & $\begin{array}{r}32.9 \\
(100)\end{array}$ & $\begin{array}{c}29.9 \\
(91.0)\end{array}$ & - & - & - & - \\
\hline 1101 & $\mathrm{SiO}_{2}-\mathrm{ZrO}_{2}$ & 510 & 180 & 0.957 & $\begin{array}{c}22.4 \\
(100)\end{array}$ & $\begin{array}{c}18.3 \\
(81.7)\end{array}$ & - & - & - & - \\
\hline 4001 & $\mathrm{SiO}_{2}-\mathrm{PbO}-1$ & 500 & 220 & 0.658 & $\begin{array}{r}3.8 \\
(100)\end{array}$ & $2.0 \mathrm{cc}$ & - & - & - & - \\
\hline
\end{tabular}




\begin{tabular}{|c|c|c|c|c|c|c|c|c|c|c|c|c|}
\hline \multirow{4}{*}{ No. } & \multirow{4}{*}{ 触 } & \multirow{3}{*}{\multicolumn{2}{|c|}{ 粗 油 炭 素 }} & \multicolumn{9}{|c|}{ 生 成 ガ ス } \\
\hline & & & & \multirow{3}{*}{$\begin{array}{c}\text { 全 量 } \\
l \\
l\end{array}$} & & & & 成 & 分 \% & & & \\
\hline & & & & & \multirow{2}{*}{$\mathrm{CO}_{2}$} & \multirow{2}{*}{$\mathrm{O}_{2}$} & \multirow{2}{*}{$\mathrm{CO}$} & \multirow{2}{*}{$\begin{array}{l}\text { プ } \\
\text { ピレン }\end{array}$} & \multirow{2}{*}{$\begin{array}{l}\text { エチ } \\
\text { レン }\end{array}$} & \multicolumn{2}{|c|}{ パラフィン } & \\
\hline & & 臭素価 & 生成量 & & & & & & & F均炭素数 & $\%$ & $11_{2}$ \\
\hline 801 & $\mathrm{SiO}_{2}-\mathrm{MgO}-1$ & 96 & $\begin{array}{c}0.114 \\
(0.34)\end{array}$ & $\begin{array}{r}3.98 \\
(11.9)\end{array}$ & 0.6 & 0.8 & 00 & $\begin{array}{r}8.13 \\
(18.3)\end{array}$ & 0.8 & 1.38 & 3.4 & 2.3 \\
\hline 901 & $\mathrm{Al}_{2} \mathrm{O}_{3}-\mathrm{ZrO}_{2}-1$ & - & - & $\begin{array}{r}4.24 \\
(16.2)\end{array}$ & 0.7 & 2.7 & - & $\begin{array}{l}423 \\
(12.8)\end{array}$ & 2.9 & 1.36 & 9.0 & 25.2 \\
\hline 902 & 上 & - & - & $\begin{array}{l}1.49 \\
(7.1)\end{array}$ & 0.0 & - & - & $\begin{array}{l}52.3 \\
(6.93)\end{array}$ & - & - & - & - \\
\hline 5001 & $\mathrm{Al}_{2} \mathrm{O}_{3}-\mathrm{ZrO}_{2}-2$ & - & - & $\begin{array}{r}057 \\
(2.70)\end{array}$ & - & - & - & $\begin{array}{l}10.35 \\
(053)\end{array}$ & - & - & - & - \\
\hline 3001 & $\mathrm{Al}_{2} \mathrm{O}_{3}-\mathrm{B}_{2} \mathrm{O}_{3}-1$ & - & - & $\begin{array}{r}3.92 \\
(13.5)\end{array}$ & 06 & 0.2 & 1.2 & $\begin{array}{c}58.0 \\
(14.73)\end{array}$ & 12 & 137 & 11.4 & 14.7 \\
\hline 1001 & $\mathrm{TiO}_{2}-\mathrm{B}_{2} \mathrm{O}_{3}$ & - & - & $\begin{array}{r}025 \\
(3 \cdot 15)\end{array}$ & - & - & - & - & - & - & - & - \\
\hline 1601 & $\mathrm{SiO}_{2}-\mathrm{CaO}-1$ & - & 一 & $\begin{array}{r}0.15 \\
(1.28)\end{array}$ & - & - & - & - & - & 一 & - & 一 \\
\hline 1801. & $\mathrm{SiO}_{2}-\mathrm{CaO}-3$ & - & - & $\begin{array}{r}050 \\
(2.18)\end{array}$ & - & - & - & - & - & - & - & - \\
\hline 1901 & $\mathrm{SiO}_{2}-\mathrm{CaO}-4$ & - & - & $\begin{array}{r}0.29 \\
(0.91)\end{array}$ & - & - & 一 & $\begin{array}{l}147 \\
(025)\end{array}$ & - & - & - & - \\
\hline 1501 & $\mathrm{SiO}_{2}-\mathrm{SrO}-1$ & - & - & $\begin{array}{r}0.18 \\
(3.00)\end{array}$ & - & - & - & $\begin{array}{r}30 \\
(0.17)\end{array}$ & - & - & - & - \\
\hline 1401 & $\mathrm{SiO}_{2}-\mathrm{ZnO}-1$ & - & - & $\begin{array}{r}2.41 \\
(8.10)\end{array}$ & 0.6 & 0.2 & 2.1 & $\begin{array}{c}33.7 \\
(5.10)\end{array}$ & 0.8 & 1.50 & 5.4 & 30.4 \\
\hline 1402 & $\mathrm{SiO}_{2}-\mathrm{ZnO}-2$ & - & - & $\begin{array}{r}1.25 \\
(3.80)\end{array}$ & - & - & - & $\begin{array}{c}15.4 \\
(1.10)\end{array}$ & - & - & - & 一 \\
\hline 1101 & $\mathrm{SiO}_{2} \mathrm{ZrO}_{2}$ & - & - & $\begin{array}{r}1.49 \\
(6.65)\end{array}$ & 0.6 & 1.4 & 0.0 & $\begin{array}{c}62.1 \\
(7.80)\end{array}$ & 0.5 & 1.67 & 2.4 & 4.7 \\
\hline 4001 & $\mathrm{SiO}_{2}-\mathrm{PbO}-1$ & - & - & $\begin{array}{c}0.1 \\
(264)\end{array}$ & - & - & 一 & ${ }^{20.2}$ & - & - & - & - \\
\hline
\end{tabular}

$\mathrm{g}$ を $\mathrm{AlCl}_{3} \cdot 6 \mathrm{H}_{2} \mathrm{O} 48 \mathrm{~g}$ ⿸水 $500 \mathrm{cc}$ に溶解した液に湞 け $100^{\circ} \mathrm{C}$ て $1 \mathrm{hr}$ 沸腾させる。さらに蒸発且て水分か ほとんとなくなるまて煮つめ，洗涤，乾燥して用いる。 $\mathrm{SiO}_{2}-\mathrm{Al}_{2} \mathrm{O}_{3}-5$ シリカゾル $235 \mathrm{~g}\left(\mathrm{SiO}_{2} 0.80 \mathrm{~mol}\right.$ 含有 $)$ を $\mathrm{Al}\left(\mathrm{NO}_{3}\right)_{3} \cdot 9 \mathrm{H}_{2} \mathrm{O} 17.6 \mathrm{~g}$ の水溶液に少し加熱して 筧捧しなから混合し，これに $1864 \% \mathrm{NH}_{4} \mathrm{OH} 100 \mathrm{cc}$ を加元る。沈澱を瀘過, 水洗, 乾燥, 錠郕とする。 $\mathrm{SiO}_{2}-\mathrm{Al}_{2} \mathrm{O}_{3}-6$ シリカゾルとアルミナゾルとをホール ミル中で練りあわせてつくつたものてある。

以上の各触媒はいつ机子使用前 $200^{\circ} \mathrm{C}, 500^{\circ} \mathrm{C}$ の 2 段て加熱処理して用いる。

\section{（II） シリカーアルミナ以外の成分触媒}

周期律表第 2,3, 4 属元素の酸什物を 2 つ組合せ九二成 分系触媒を合成し p-cymeneの接触分解を招こない， 分解機㮖定研究し，あわせて脫アルキル分解能を比較 した。実跧法は前と同じてある。結果は第 2 表に示す と却りである。(括孤队の数学は第 1 表と同じ)

結果に刘する考察

1) $\mathrm{SiO}_{2}-\mathrm{MgO}-1, \mathrm{Al}_{2} \mathrm{O}_{3}-\mathrm{B}_{2} \mathrm{O}_{3}$ 等は脫アルキル分 解能高くその分解穖檴はほほ活性白土と同悦てある。

2）シリカ含有触媒について：珪酸ソーダと各金属 塩を共沈させてつくつた触媒について，そのプロビレ ン発生量の順序に各触媒を並べるとつぎの如くなる。 (たたし $\mathrm{SiO}_{2}-\mathrm{ZrO}_{2}$ 触媒のみシリカゾルを优用。ま た $\mathrm{SiO}_{2}-\mathrm{CaO}-1$ については生成が総量のみしか測 定しなかつたのて，この湯合に限りガス量て順位つけ た。)

$\mathrm{SiO}_{2}-\mathrm{Al}_{2} \mathrm{O}_{3}-2>\mathrm{SiO}_{2}-\mathrm{MgO}-1>\mathrm{SiO}_{2}-\mathrm{ZrO}_{2}>\mathrm{SiO}_{2}-$ $\mathrm{ZnO}-1>\mathrm{SiO}_{2}-\mathrm{ZnO}-2>\mathrm{SiO}_{2}-\mathrm{PbO}-1>\mathrm{SiO}_{2}-\mathrm{CaO}-$ 1) $\mathrm{SiO}_{2}-\mathrm{CaO}-4>\mathrm{SiO}_{2}-\mathrm{SrO}-1$

一方 $\mathrm{SiO}_{2}$ に刘して組合された各酸化物中の金属元 素の原子牛径をしめすとつぎのと捻りでる。(Goldschmidt による值て配位数 12 のときの值。単位 $\AA$ )

A1 1.43, Mg 1.60, Zr 1.60, Zn 1.37, Pb 1.74, Ca 1.97, Sr 2.16 これをみると触媒のプロピレン発 生量順位と $\mathrm{SiO}_{2}$ に刘して組合された酸化物の金属元 
素の原子卅徍の墰大順位とは $\mathrm{Zn}$ の場合を例外として 一致している。(ただし元素の配位数に対して考慮して ない。

ここに注意さるべきことは，前のシリカーアルミナ 触媒の場合と異つてプロビレンの発生量か減少するを ともに一，二の例外はあるがガス発生量も減少してい ることである。亦なわちこの場合上述の金属元素の原 子牛径增大とともに先の触蝶を用いた場合，ガス発生 量, 生成ガス中のプロピレン含有率はと为に減少し, したがつて発生プロビレン量も減少することである。 これは上述の原子牛径堙大とともに，吸着面積を減少 させる作用と瞈アルキル分解意減少させる作用とが重 つて起つているように想像される。

3）アルミナ含有触媒について：この触媒について は此較実験例必少く触媒調製法子買るので比較は困較 であるが，原子本径の小さい硼素を含む $\mathrm{Al}_{2} \mathrm{O}_{3}-\mathrm{B}_{2} \mathrm{O}_{3}$ 1 触媒がかなりプロビレン発生量汐いことは注目さ るべきことと考觉る。

\section{触媒調製法}

$\mathrm{SiO}_{2}-\mathrm{MgO}-1$ 比重 1.39 珪酸ッーダ $167.3 \mathrm{~g}$ 学水 $2 l$ で希㽖した溶液中に $\mathrm{MgCl}_{2} \cdot 6 \mathrm{H}_{2} \mathrm{O} \quad 162 \mathrm{~g}$ 水 $500 \mathrm{cc}$ に溶解した溶液を加兄る，沈搌を瀘狦水洗， $110^{\circ} \mathrm{C}$ で 乾燥与る。

$\mathrm{Al}_{2} \mathrm{O}_{3}-\mathrm{ZrO}_{2}-1 \quad \mathrm{Al}_{2}\left(\mathrm{SO}_{4}\right)_{3} \cdot 18 \mathrm{H}_{2} \mathrm{O} 100 \mathrm{~g}, \mathrm{Zr}\left(\mathrm{NO}_{3}\right)_{4}$ . $5 \mathrm{H}_{2} \mathrm{O} 7.8 \mathrm{~g}$, conc $\mathrm{HCl} 9.5 \mathrm{cc}, \mathrm{H}_{2} \mathrm{O} 20 \mathrm{ce}$ の溶液中に $\mathrm{NaOH} 20.1 \mathrm{~g}, \mathrm{Na}_{2} \mathrm{CO}_{3} 26.5 \mathrm{~g}, \mathrm{H}_{2} \mathrm{O} 112 \mathrm{~g}$ の溶液老攪 拌しながら加觉るとしばらくして急に大量の沈澱がで きる。これに $\mathrm{NaOH}$ 溶液省少し加えて弱アルカリ性 として瀘過, 水洗, 乾燥, 錠剂とする。 $\mathrm{Al}_{2} \mathrm{O}_{3}-\mathrm{ZrO}_{2}-$ $2 \mathrm{Al}_{2}\left(\mathrm{SO}_{4}\right)_{3} \cdot 18 \mathrm{H}_{2} \mathrm{O} 100 \mathrm{~g}, \mathrm{Zr}\left(\mathrm{NO}_{3}\right)_{4} \cdot 5 \mathrm{H}_{2} \mathrm{O} \quad 7.8 \mathrm{~g}$, conc $\mathrm{HCl}$ 9.5ce, 水 $300 \mathrm{~g}$ 中に conc $\mathrm{NH}_{4} \mathrm{OH} 95 \mathrm{cc}$ 它 加之, 沈澱を瀘過, 水洗, 乾燥, 錠刜とする。

$\mathrm{TiO}_{2}-\mathrm{B}_{2} \mathrm{O}_{3} \mathrm{Ti}(\mathrm{OH})_{4} 35 \mathrm{~g}$ を矹酸 $6.43 \mathrm{~g}$ を溶解し た水溶液中に混じ蒸発血中で加熱攪找して濃縮し乾燥 錠剂とする。

$\mathrm{SiO}_{2}-\mathrm{ZrO}_{2}$ シリカゾル $66 \mathrm{~g}\left(\mathrm{SiO}_{2} 0.226 \mathrm{~mol}\right.$ 含有 $)$ に $\mathrm{Zr}\left(\mathrm{NO}_{3}\right)_{4} \cdot 5 \mathrm{H}_{2} \mathrm{O} 7.1 \mathrm{~g}$ の水溶液を加兄, 巳らに $\mathrm{Na}_{2}$

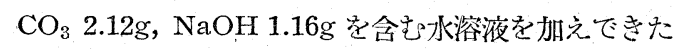
沈澱を水洗，乾燥し，錠郕とする。

$\mathrm{SiO}_{2}-\mathrm{ZnO}-1 \mathrm{ZnCl}_{2} 109 \mathrm{~g}$ を $300 \mathrm{cc}$ の水に溶解し, これを比重 1.39 の珠酸ソーダ $167.3 \mathrm{~g}$ を水 $2 l$ で希釈 した液に攪拌しながら加えて沈澱をつくり， $\mathrm{CI}^{\prime}$ 方認 められなくなるまで水洗し $110 \sim 115^{\circ} \mathrm{C}$ で乾燥, 錠剮 とする。

$\mathrm{SiO}_{2}-\mathrm{SrO}-1$ 上記 $\mathrm{SiO}_{2}-\mathrm{ZnO}-1$ 調製法において $\mathrm{Zn}$
$\mathrm{Cl}_{2}$ のかわりに $\mathrm{SrCl}_{2} \cdot \mathrm{SrCl}_{2} \cdot 6 \mathrm{H}_{2} \mathrm{O} 106.7 \mathrm{~g}$ を用いる 他は同じである。

$\mathrm{SiO}_{2}-\mathrm{CaO}-1$ 同じく $\mathrm{ZnCl}_{2}$ のかわりに $\mathrm{Ca}\left(\mathrm{NO}_{3}\right)_{2}$ 。 $2 \mathrm{H}_{2} \mathrm{O} 160.1 \mathrm{~g}$ を用いる他は同じでまる。

$\mathrm{SiO}_{2}-\mathrm{CaO}-3 \mathrm{CaO} 45.3 \mathrm{~g}$ を水 $500 \mathrm{cc}$ で練り,シリカ ゾル $235 \mathrm{~g}\left(\mathrm{SiO}_{2} 0.80 \mathrm{~mol}\right.$ 含有) を水 $100 \mathrm{cc}$ で希釈し た液に筧拌しながら加える。沈澱を瀘過, 水洗, 乾燥, 錠鼡とする。

SiO $2-\mathrm{CaO}-4$ 比重 1.39 の珪酸ソーダ $167.3 \mathrm{~g}$ を水 $120 \mathrm{cc}$ で希釈した液を $\mathrm{Ca}\left(\mathrm{NO}_{3}\right)_{2} \cdot 2 \mathrm{H}_{2} \mathrm{O} \quad 49.4 \mathrm{~g}$ を水 1,500 cc に溶解した液に攪捧下に徐々に加之一, 沈澱 を濾過, 水洗, 乾燥, 錠耠とする。

$\mathrm{SiO}_{2}-\mathrm{ZnO}-2$ 比重 1.39 の珪酸ソーダ $167.3 \mathrm{~g}$ 水 $120 \mathrm{cc}$ で希択した液をを $\mathrm{ZnCl}_{2} 33.7 \mathrm{~g}$ を $1 l$ の水に溶

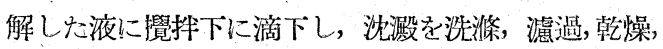
錠削とする。

$\mathrm{Al}_{2} \mathrm{O}_{3}-\mathrm{B}_{2} \mathrm{O}_{3}-1 \mathrm{AlCl}_{3} \cdot 6 \mathrm{H}_{2} \mathrm{O}$ 150g に $12 \mathrm{~N}$ の $\mathrm{NH}_{4}$ $\mathrm{OH} 50 \mathrm{cc}$ を加穴 $\mathrm{Al}(\mathrm{OH})_{3}$ の沈澱をつくり。沪過, 水洗しこれを $\mathrm{H}_{3} \mathrm{BO}_{3} 38.4 \mathrm{~g}$ 含含水溶液 $1 l$ に加光, 湯浴上で約 $20 \mathrm{hr}$ 筧拌練合せ, 沪過, 水洗, 乾燥, 錠 郕とする。

$\mathrm{SiO}_{2}-\mathrm{PbO}-1 . \mathrm{SiO}_{2}-\mathrm{ZnO}-1$ の調製法に扮いて $\mathrm{ZnCl}_{2}$ のかわりに $\mathrm{Pb}\left(\mathrm{NO}_{3}\right)_{2} 264.8 \mathrm{~g}$ を用いる他は同じであ る。

以上の各触媒は使用前 $200^{\circ} \mathrm{C}, 500^{\circ} \mathrm{C}$ で二段に加爇 処理与る。

\section{（III）触媒の X線解析}

1. 前報で述べた活性白土，上揭のシリカーアルミ ナ触媒, またそれ以外のシリカーアルミナ型二成分系 触媒も脫アルキル分解能か㵔るしく異るものがある。 その美異を知る一助として触媒の組成を分析し，末た デバィ・シェーラー粉未法で触媒の X線迴析写百をと つた結果を触媒のプロピレン発生量の順に第 3 表に, また第 4 表に参考として $\mathrm{Al}_{2} \mathrm{O}_{3}$ 拉よびシリカゲルの み(加熱処理はシリカーアルミナ触媒の場合と同じ) のX線建析結果をあげる。

\section{結果に対する考察}

触媒組成の分析はX線廻析に対寸る参考資料和上び 組成变化の触媒の分解能に対寸る参考のためにおこな つたが，シリカーアルミナ触媒に対するものを比較例 としてみて为組成变化は分解能に対して余り大きな影 響を有しないよらである。

$\mathrm{X}$ 線迴折の結果は $\mathrm{SiO}_{2}$ を含む触媒ではシリゲル単 独の場合と，また $\mathrm{Al}_{2} \mathrm{O}_{3}$ を含む触媒では $\mathrm{Al}_{2} \mathrm{O}_{3}$ 単独 の場合と同じよらな迴折線が得られている。すなおち 
第 3 表 シリカ・アルミナ型触媒による p-cymene の接触分解反応

\begin{tabular}{|c|c|c|c|c|c|}
\hline No. & 触 & \multicolumn{2}{|c|}{ 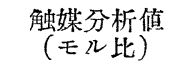 } & \multicolumn{2}{|c|}{$\begin{array}{c}\text { 触媒のX } \mathrm{X} \text { 線畐折 } \\
\text { 强度 } \mathrm{d}(\AA)\end{array}$} \\
\hline 1 & $\mathrm{SiO}_{2}-\mathrm{Al}_{2} \mathrm{O}_{3}-2$ & $\begin{array}{l}\mathrm{SiO}_{2} \\
10.45\end{array}$ & $\begin{array}{r}\mathrm{Al}_{2} \mathrm{O}_{3} \\
1\end{array}$ & $\mathrm{Sb}$ & 4.12 \\
\hline 2 & $\mathrm{SiO}_{2}-\mathrm{MgO}-1$ & $\begin{array}{r}\mathrm{SiO}_{2} \\
3.08\end{array}$ & $\mathrm{MgO}_{1}$ & $\begin{array}{l}\mathrm{Sb} \\
\mathrm{W}\end{array}$ & $\begin{array}{l}4.37 \\
257\end{array}$ \\
\hline 3 & 活性白土 1 & $\begin{array}{r}\mathrm{SiO}_{2} \\
9.82\end{array}$ & $\begin{array}{r}\mathrm{Al}_{2} \mathrm{O}_{3} \\
1\end{array}$ & & \\
\hline 4 & 活性白土 2 & $\begin{array}{l}\mathrm{SiO}_{2} \\
12.07\end{array}$ & $\begin{array}{r}\mathrm{Al}_{2} \mathrm{O}_{3} \\
1\end{array}$ & $\stackrel{\mathrm{S}}{\mathrm{W}}$ & $\begin{array}{l}4.18 \\
2.54\end{array}$ \\
\hline 5 & $\mathrm{Al}_{2} \mathrm{O}_{2}-\mathrm{B}_{2} \mathrm{O}_{3}-1$ & $\begin{array}{c}\mathrm{Al}_{2} \mathrm{O}_{3} \\
6.26\end{array}$ & $\begin{array}{r}\mathrm{B}_{2} \mathrm{O}_{3} \\
\quad 1\end{array}$ & $\begin{array}{l}\mathrm{Sb} \\
\mathrm{W}\end{array}$ & $\begin{array}{l}4.37 \\
1.444\end{array}$ \\
\hline 6 & $\mathrm{SiO}_{2}-\mathrm{Al}_{2} \mathrm{O}_{3}-5$ & & & & \\
\hline 7 & $\mathrm{Al}_{2} \mathrm{O}_{3}-\mathrm{ZrO}_{2}-1$ & $\begin{array}{c}\mathrm{Al}_{2} \mathrm{O}_{3} \\
5.18\end{array}$ & $\begin{array}{r}\mathrm{ZrO}_{2} \\
\quad 1\end{array}$ & $\begin{array}{l}\mathrm{Sb} \\
\mathrm{W}\end{array}$ & $\begin{array}{l}4.20 \\
1.400\end{array}$ \\
\hline 8 & $\mathrm{SiO}_{2}-\mathrm{Al}_{2} \mathrm{O}_{3}-6$ & $\begin{array}{l}\mathrm{SiO}_{2} \\
8.31\end{array}$ & $\begin{array}{r}\mathrm{Al}_{2} \mathrm{O}_{3} \\
I\end{array}$ & $\mathrm{Sb}$ & 4.27 \\
\hline 9 & $\mathrm{SiO}_{2}-\mathrm{ZrO}_{2}$ & & & & \\
\hline 10 & $\mathrm{SiO}_{2}-\mathrm{ZnO}-1$ & & & & \\
\hline 11 & $\mathrm{SiO}_{2}-\mathrm{ZnO}-2$ & $\begin{array}{l}\mathrm{SiO}_{2} \\
\quad 3.27\end{array}$ & $\mathrm{ZnO}_{1}$ & $\mathrm{Sb}$ & 4.27 \\
\hline 12 & $\mathrm{Al}_{2} \mathrm{O}_{3}-\mathrm{ZrO}_{2}-2$ & & & & \\
\hline 13 & $\mathrm{TiO}_{2}-\mathrm{B}_{2} \mathrm{O}_{3}$ & & & & \\
\hline 14 & $\mathrm{SiO}_{2}-\mathrm{PbO}-1$ & & & & \\
\hline 15 & $\mathrm{SiO}_{2}-\mathrm{CaO}-3$ & & & & \\
\hline 16 & $\mathrm{SiO}_{2}-\mathrm{CaO}-1$ & $\begin{array}{l}\mathrm{SiO}_{2} \\
3.16\end{array}$ & $\mathrm{CaO}_{1}$ & & \\
\hline 17 & $\mathrm{SiO}_{2}-\mathrm{CaO}-4$ & $\begin{array}{l}\mathrm{SiO}_{2} \\
3.51\end{array}$ & $\mathrm{CaO}_{1}$ & $\mathrm{Sb}$ & 4.30 \\
\hline 18 & $\mathrm{SiO}_{2}-\mathrm{SrO}-1$ & $\begin{array}{l}\mathrm{SiO}_{2} \\
2.66\end{array}$ & $\mathrm{SrO}_{1}$ & & \\
\hline
\end{tabular}

第 4 表 $\gamma-\mathbf{A l}_{2} \mathbf{O}_{3}$, シリカゲルのX線㢠折

\begin{tabular}{|c|c|c|c|}
\hline \multicolumn{2}{|c|}{$\gamma-\mathrm{Al}_{2} \mathrm{O}_{3}$} & \multicolumn{2}{|c|}{ シリカゲル } \\
\hline 强 度 & $\mathrm{d}(\AA)$ & 强 度 & $\mathrm{d}(\AA)$ \\
\hline $\mathrm{S}$ & 428 & $\mathrm{~S}$ & 4.07 \\
\hline VW & 2.00 & W & 252 \\
\hline W & 1.51 & & \\
\hline $\mathrm{M}$ & 1.42 & & \\
\hline
\end{tabular}

涯加した他の酸化物の影響かあらわれていない。ただ しシッカゲルアルミナ単独の場合に比して幾分格子 間隔かひろからたような恰好になつているか，その程 度と分解能との間には関係力認妨礼ない $\left(\mathrm{Al}_{2} \mathrm{O}_{3}-\mathrm{Zr}\right.$ $\mathrm{O}_{2}$ のみわすが上と反対に狹つている)迴折線の数も 少く，X線結果からたけては分解能との間に確かな推 論旡てき難いか，概してX線迴折の点からは差異か認 められないようである。第1図に迴折の参考として触 媒粒子の人きさを知るために撮影した $\mathrm{SiO}_{2}-\mathrm{Al}_{2} \mathrm{O}_{3}-2$ の電子顕微鏡写傎をあげる。

第1図 $\mathrm{SiO}_{2}-\mathrm{Al}_{2} \mathrm{O}_{3}-2$ の電子顕微鏡写眞

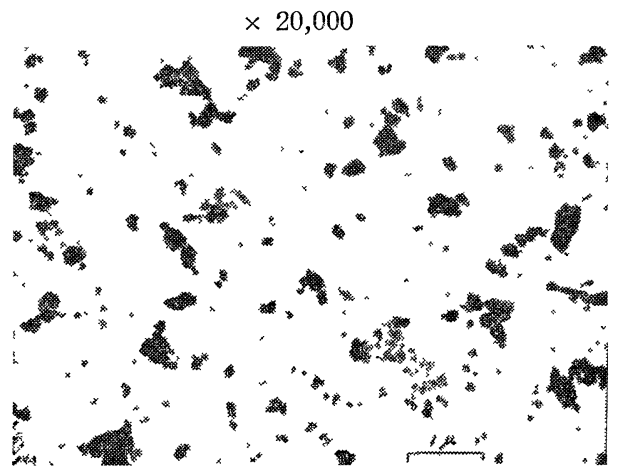

本研究に際し御指導をいただいた三井化学目黑研究 所長安田三郎氏, ならびに発表に際し種々御伝宜を与 之られた副社長榎本好文氏, 参与岩崎高雄氏, 所長鳥

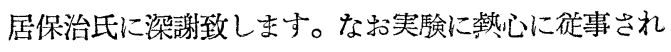
た広瀬敏男君に厚く感謝致します。 


\title{
Catalytic decomposition of p-Cymene by Silica-Alumina type catalysts
}

\author{
By Masafumi Maki
}

(Formerly of Meguro Institute of Chemical Research of Mitsui Chem. Ind. Co., Ltd.)

SYNOPSIS :-Mechanism of catalytic decomposition of p-Cymene by Silica-Alumina catalysts which prepared with various methods was studied and dealkylation ability of individual catalyst was estimated. Same experiment was tried with other SilicaAlumina type catalysts consisted of two oxides and the element of which belongs to the Periodic System JI, III, IV. Among which, $\mathrm{SiO}_{2}-\mathrm{MgO}, \mathrm{Al}_{2} \mathrm{O}_{3}-\mathrm{B}_{2} \mathrm{O}_{3}$ and $\mathrm{Al}_{2} \mathrm{O}_{3}-\mathrm{ZrO}_{2}$ catalysts have been admitted to have high dealkylation ability. Generally speaking, in the case of catalyst which consisted of Silica and oxide, the metal element of oxide belongs to Periodic System II, III, IV, the larger the atomic radius of its element, the smaller the amount of Propylene which produced by catalytic dealkylation of p-Cymene with this catalyst.

\section{待筀の「燃料便覽」発売！}

現場で役立つ生きた燃料技泪データ

\section{本会々員に限り特価提供}

\begin{tabular}{|c|c|c|c|}
\hline クロース製 & $\begin{array}{l}\text { 定 侕 } \\
1,200 円\end{array}$ & 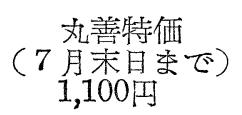 & 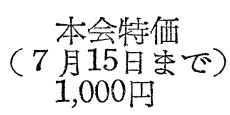 \\
\hline 総 革 製 & 1,600円 & 1,500円 & 1,350円 \\
\hline
\end{tabular}

前回本誌 (312号) 会告筧の丸善特佂 1,000円とをつて特りましをのは誤りとつき 1,100内 と訂政します。

東京都中央区寣町 3 ○ 1

社団法人 燃 料 協 会 